\title{
PERSEPSI KONSUMEN THEMATIC COFFEE HOUSE TERHADAP MEREK, KUALITAS PRODUK DAN PELAYANAN SERTA NILAI PELANGGAN PRODUK KOPI LOKAL (SURVEI KONSUMEN FILOSOFI KOPI JAKARTA SELATAN)
}

\author{
Hesty Nurul Utami ${ }^{1}$, Nuri Kamilia ${ }^{2}$ \\ ${ }^{1}$ Program Studi Agribisnis Universitas Padjadjaran, Jatinangor, Indonesia \\ ${ }^{2}$ Program Studi Agribisnis Universitas Padjadjaran, Jatinangor, Indonesia
}

\section{e-mail: hesty.nurul@unpad.ac.id}

\begin{abstract}
Abstrak
Indonesia merupakan salah satu negara penghasil kopi terbesar di dunia dengan tingkat konsumsi kopi yang diproyeksikan terus meningkat setiap tahunserta didukungmeningkatnya jumlahcoffee house di Indonesia. Filosofi Kopi merupakan coffee houseyang beroperasi kurang dari satu tahun di wilayah Jakarta dengan konsepthematic coffee house yang menjual kopi lokal khas Indonesia yang harus bersaing dengan coffee houseinternasional yang membuka cabangnya di kota besar seperti Jakarta.Penelitian ini bertujuan untuk menggambarkan persepsi konsumen terhadap kesadaran merek, kualitaskopi, kualitas pelayanan dan nilai pelanggan di Filosofi Kopi untuk meningkatkan daya saing coffee house lokal di Indonesia. Membangun merek dapat memberikan perlindungan secara legal terhadap keunikan sebuah merek, sedangkan kualitas produk dan kualitas pelayanan dapat meningkatkan nilai yang dirasakan konsumen. Sehingga suatu produk akan berhasil jika memberikan nilai yang lebih tinggi bagi konsumen dan dapat dijadikan sebagai alat ukur daya saing. Metode penelitian yang digunakan adalah metode deskriptif kuantitatif dengan menggunakan diagram ular sebagai alat analisis data. Sampel dipilih melalui teknik proporsional stratified random samplingterhadap 60 orang responden. Hasil penelitian menunjukkan bahwa konsumen sulit untuk mengingat nama jenis kopi yang dijual namun mudah mengenali logo dengan perspektif positif atas rasa dan aroma kopi lokal yang superior dan cara penyajian kopi yang tepat, namun belum didukung fasilitas layanan coffee house yang memuaskan konsumen. Edukasi konsumen dan kampanye pemasaran melalui merek dan kualitas produkdiperlukan untuk meningkatkan daya saing kopi lokal.
\end{abstract}

Kata kunci: Kopi lokal, Jasa Makanan,Penciptaan Nilai, Perilaku Konsumen

\begin{abstract}
Indonesia is one of the largest coffee producer in the world with coffee consumption level predicted to be increased every year and supported by the rise of coffee house in Indonesia. Filosofi Kopi is a brand new coffee house with thematic and unique conceptin Jakarta that sold Indonesia local coffee and should compete with numerous international coffee house brand that open their store branch in big city such as Jakarta. This study objectives are to describecustomers perspective on brand awareness, coffee quality, service quality and customer value to improve business competitiveness.Building brand could give legal protection for brand uniqueness, while product quality and service quality are predicted to improve customer perceived value. Thus a product successfulness is undeniable with favour to high customer value that utilize as tool for competitiveness. The research method applied descriptive quantitativewith snake diagram for data analysis. Proportional stratified random
\end{abstract}


sampling technique was applied to 60 respondents. The results show that customer face difficulties recognizing local coffee names while it is easier to remember product logo. Filosofi Kopi show positive perspective on local coffee product quality by product flavour and aroma, while service quality superiority gain through precise coffee presentation but less supported physical evidence of a coffee house to reveal consumer satisfaction. Customer education and marketing campaign on product brand and product quality required to improve local coffee competitiveness.

Keywords: Local Coffee, Food Services, Value Creation, Consumer Behavior

\section{PENDAHULUAN}

Ditetapkannya Masyarakat
Ekonomi ASEAN (MEA) saat ini
menyebabkan persaingan usaha
menjadi semakin ketat antara produk
luar negeri dan produk dalam negeri.
Satu hal yang dapat dilakukan oleh para
pelaku bisnis saat ini dalam menghadapi
MEA adalah dengan memulihkan daya
saing produk Indonesia(Dirjen Kerja
Sama Perdagangan Internasional, 2015). Hal ini pun juga mempengaruhi persaingan pada komoditas kopi yang merupakan komoditas tropis utama yang diperdagangkan di seluruh dunia dengan kontribusi setengah dari total ekspor komoditas tropis. Menurut data FAO, Indonesia tercatat sebagai negara penghasil kopi terbesar ketiga setelah Brazil dan Vietnam.

Produksi kopi yang tinggi di Indonesia menjadi sebuah peluang bagi pelaku usaha untuk mengolahnya menjadi sebuah minuman olahan berbahan dasar kopi karena kopi merupakan sumber alami kafein, zat yang dapat menyebabkan peningkatan kewaspadaan dan mengurangi kelelahan. Minuman kopi dengan bahan dasar ekstrak biji kopi dikonsumsi sekitar 2,25 milyar gelas setiap hari di seluruh dunia (Badan Pusat Statistik, 2015). Konsumsi minuman kopi di Indonesia juga diperkirakan akan terus meningkat setiap tahunnya dikarenakan minum kopi sudah menjadi sebuah kebiasaan atau gaya hidup (lifestyle) bagi beberapa kalangan masyarakat (gambar 1).

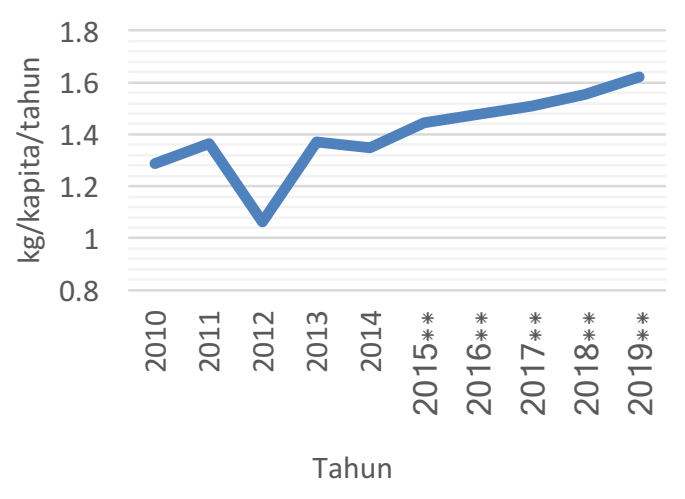

Gambar 1. Konsumsi Kopi di Indonesia Sumber: BPS (2015, diolah)

Keterangan: **Proyeksi

Peningkatan konsumsi tersebut menyebabkan maraknya coffee house yang hadir di Indonesia. Nilai pertumbuhan coffee house di Indonesia merupakan yang terbesar pada tahun 2011, yaitu melebihi $15 \%$ dengan Starbucks dan The Coffee Bean \& Tea Leaf sebagai merek coffee house internasional yang berada diposisi pertama dan ketiga, sedangkan pada posisi kedua ditempati oleh Excelso Café yang merupakan merek coffee house lokal. Banyak dari beberapa coffee house saat ini digunakan sebagai tempat untuk mengerjakan tugas kuliah, rapat atau berdiskusi karena kopi terbukti meningkatkan konsentrasi. Selain mendapatkan stimulus dari kafein, interaksi dengan pengunjung coffee house lain menjadi lebih baik karena peminum kopi terstimulus kopi sehingga membuatnya tenang serta dapat berkomunikasi dengan lebih baik dan santai (Samsura, 2012). 
Di tengah maraknya persaingan yang ketat antara coffee house di Indonesia khususnya di kota besar seperti Jakarta, banyak merek - merek coffee house internasional yang merek yang sudah dikenal masyarakat membuka cabang tokonya di kota - kota besar seperti Jakarta. Sehingga pebisnis lokal yang membuka bisnis coffee house yang menjual kopi khas Indonesia dengan tema yang berbeda - beda harus berusaha keras untuk dapat bersaing dengan merek internasional. Dengan maraknya coffee house internasional maupun lokal di Indonesia saat ini menyebabkan pilihan bagi konsumen untuk memilih coffee house yang akan dikunjungi menjadi sangat beragam. Dalam menghadapi persaingan bisnis ini maka perlu adanya diferensiasi yang dikembangkan oleh para pebisnis kopi lokal sehingga konsumen tetap memiliki ketertarikan terhadap konsumsi kopi lokal di di coffee house lokal.

Strategi yang dapat dikembangkan adalah dengan melakukan strategi bisnis berorientasi pasar atau konsumen (market driven). Untuk membuat keputusan pembelian konsumen kepada coffee house lokal, maka perlu adanya intervensi terhadap perilaku konsumen dalam membuat keputusan sehingga akan mempengaruhi nilai atas produk yang dirasakan oleh konsumen yang juga akan mempengaruhi kepuasan konsumen atas produk yang dibeli atau dikonsumsinya. Kepuasan pelanggan dilihat dapat mempengaruhi intensitas pembelian kembali yang memberi dampak terhadap pendapatan dan keuntungan perusahaan di masa depan (Qin, 2009).

Upaya peningkatan daya saing tersebut dapat dilakukan salah satunya dengan penerapan strategi merek dikarenakan banyaknya perusahaan yang bermunculan dalam bidang usaha sejenis dan menghasilkan produk yang sama sehingga pemberian nama merek dianggap penting. Strategi manajemen merek meliputi desain dan implementasi dari program pemasaran dan aktifitas untuk membangun, mengukur, dan mengelola brand equity (Keller, 2013). Pada suatu perusahaan, merek berguna untuk memberikan perlindungan secara legal terhadap keunikan sebuah nama merek yang dapat dilindungi oleh merek dagang (Kotler dkk, 2009). Sebuah identitas merek yang kuat dan konsisten dapat memberikan posisi serta identitas yang kuat pula bagi sebuah perusahaan di pasar sehingga membuat konsumen menjadi lebih mudah untuk mengingat dan terhubung dengan merek tersebut (Aaker, 2002).

Bagi sebuah produk baru maka strategi merek yang dapat dilakukan adalah untuk memunculkan kesadaran merek di mata konsumen. Kesadaran merek adalah bagaimana pelanggan dan pelanggan yang potensial sadar akan adanya bisnis beserta produknya (Gustafson dkk, 2007)

Pertimbangan konsumen sebelum membeli produk tidak hanya berdasarkan merek saja tetapi kualitas juga menjadi salah satu hal penting yang akan dipertimbangkan. The American Society on Quality dalam Kotler (2012) mendefinisikan kualitas sebagai karakteristik dari sebuah produk atau jasa yang memiliki kemampuan untuk memberikan kepuasan terhadap kebutuhan pelanggan secara nyata ataupun tersirat. Pada hospitality industry, konsumen menentukan pilihannya tidak hanya berdasarkan merek tetapi juga dari segi kualitas produk serta kualitas pelayanan. Kualitas produk adalah kemampuan sebuah produk dalam memperagakan fungsinya, hal itu termasuk keseluruhan durabilitas, reliabilitas, ketepatan, kemudahan pengoperasian, dan reparasi produk juga atribut produk lainnya (Kotler dan Amstrong, 2008). Sementara itu, Bitner dalam Johnston (1995) menyatakan bahwa kualitas pelayanan adalah kesan keseluruhan pelanggan terhadap inferiority atau superiority sebuah organisasi dan pelayanannya. Sebagai sebuah bisnis yang bergerak di dalam food service maka total kualitas yang akan dinilai oleh konsumen merupakan gabungan antara kualitas produk dan kualitas pelayanan.

Dengan persaingan yang ketat saat ini, sebuah perusahaan dikatakan berhasil jika dapat menawarkan produk atau jasa kepada konsumennya dengan 
mampu memberikan nilai dan kepuasan (value and satisfaction). Dimana nilai pelanggan (customer value) yang dimaksud yaitu perkiraan konsumen atas seluruh kemampuan produk untuk memuaskan kebutuhannya (Kotler dan Keller, 2006).nilai pelanggan merupakan perbedaan antara manfaat yang dilihat seorang pelanggan dari suatu penawaran pasar serta biaya untuk mendapatkan manfaat tersebut (Cannon dkk, 2008).

Salah satu konsep yang ditawarkan oleh pelaku usaha coffee shop adalah dengan menampilkan thematic coffee house dengan mengusung konsep penjualan minuman kopi degan atmosfer coffee house yang unik yang dibuat berdasarkan sebuah film yang dibuat dengan judil yang sama dan berfokus pada penjualan jenis kopi khas Indonesia, atmosfer coffee shop dengan tema - tema yang unik sebagai diferensiasi bisnis. Salah satu coffee house lokal yang menjadi perhatian masyarakat Jakarta adalah Filosofi Kopi (Filkop). Filkop merupakan coffee house lokal yang berada di daerah Blok $\mathrm{M}$, Melawai, Jakarta Selatan.

Coffee house Filosofi Kopi resmi dibuka pada April 2015 dan termasuk coffee house yang masih baru di kalangan masyarakat penikmat kopi. Ide untuk mendirikan Filkop adalah berasal dari latar tempat sebuah novel dan film dengan judul Filkop yang sepakat untuk direalisasikan sebagai coffee house sehingga konsep-konsep yang digunakan adalah thematic coffee house walaupun masih terbilang sebagai coffee house baru tetapi terdapat beberapa konsumen yang memang sengaja mencari coffee house ini dan datang untuk merasakan secara langsung atmosfer pada film Filosofi Kopi yang mereka saksikan. Coffee house baru seperti Filkop dianggap tepat untuk dijadikan objek penelitian berdasarkan kesesuaian variabel, yaitu kesadaran merek, kualitas produk, kualitas pelayanan dan nilai pelanggan sebagai upaya untuk meningkatkan daya saingnya terhadap coffee house internasional di Indonesia.

Penelitian ini dilakukan dengan tujuan untuk mengetahui persepsi konsumen terhadap merek coffee house lokal,kualitas produk, kualitas pelayanan, serta nilai pelanggan dari thematic coffee house Filosofi Kopi.

\section{METODE}

Desain penelitian yang digunakan adalah metode penelitian deskriptif kuantitatif. Objek penelitian ini adalah minuman kopi di Filkop. Variabel yang akan diteliti dari objek penelitian ini adalah kesadaran merek, kualitas produk, kualitas pelayanan, dan nilai pelanggan. Penelitian ini mengambil sampel di salah satu coffee house Filkop yang berada di daerah Melawai, Jakarta Selatan.

Pengambilan sampel penelitian dilakukan dengan teknik probabilty sampling dengan penentuan jumlah sampel dilakukan dengan menggunakan rumus dari Hair, dkk (1998) bahwa jumlah sampel dapat dihitung dengan menghitung jumlah variabel yang diteliti harus diwakili oleh minimal 15 sampai dengan 20 kali obervasi atau sampel. Selain itu, Gay dan Diehl (1992) berpendapat bahwa sampel haruslah sebesar-besarnya karena diasumsikan bahwa semakin banyak sampel yang diambil maka akan semakin representatif dan hasilnya dapat digeneralisasikan. Oleh karena itu, jumlah responden yang digunakan diambil jumlah terbesar yaitu sebanyak 60 responden agar hasil penelitian ini dapat lebih representatif.

Metode yang digunakan untuk mengambil sampel responden adalah proposional stratified random sampling atau pengambilan sampel secara random bertingkat dengan cara pengambilan sampel dilakukan dengan menyeleksi setiap individu yang sesuai dengan ukuran populasi dan ukuran sampel yang porposional terhadap ukuran populasi (Sarwono, 2006).

Teknik pengumpulan data penelitian menggunakan kuesioner, observasi langsung di lokasi coffee houseserta studi pustaka. Penyebaran kuesioner dilakukan untuk mengetahui respon konsumen terhadap stimuli pemasaran yang dilakukan oleh Filosofi Kopi yang terkait dengan merek, kualitas produk dan kualitas pelayanan serta 
penilaian konsumen atas nilai pelanggan yang mereka dapatkan setelah datang dan menikmati kopi di Filosofi Kopi, sedangkan observasi dilakukan untuk menambah rujukan hasil penelitian dengan melakukan pengamatan terhadap aktivitas bisnis yang terkait dengan variabel penelitian yang dilakukan di Filosofi Kopi. Skala ukur yang digunakan dalam penelitian ini adalah skala semantik diferensial menggunakan skala dari angka tujuh (sangat positif) sampai dengan satu (sangat negatif). Sedangkan untuk menginterpretasikan data yang diperolah melalui skala semantik diferensial akan digunakan profil visual, yaitu diagram ular (snake diagram).

\section{HASIL DAN PEMBAHASAN}

Responden yang datang ke Filosofi Kopi dilihat dari usianya yang paling banyak adalah responden berusia $15-22$ tahun yaitu sebanyak 39 orang dengan persentase $65 \%$, berdasarkan jenis pekerjaannya jumlah responden yang terbanyak adalah mahasiswa dan pelajar sebanyak 34 orang atau sebesar $56,7 \%$. Hal ini dikarenakan mahasiswa dan pelajar yang memiliki kebiasaan untuk berkumpul bersama temantemannya yaitu salah satunya di coffee house sebagai bentuk gaya hidup modern di kota besar dan usia remaja memiliki kecenderungan keingintahuan yang besar terhadap sesuatu yang baru.Jika dilihat berdasarkan jenis kelaminnya, responden yang datang ke Filosofi Kopilebih banyak perempuan dibandingkan laki-laki yaitu sebanyak 33 orang atau sebesar $55 \%$ untuk perempuan dan sebanyak 27 orang atau sebesar $45 \%$ untuk laki-laki. Hastuti (2003) mengatakan bahwa wanita dicitrakan lebih konsumtif dibandingkan dengan pria, yang tergambar dengan jelas dalam berbagai iklan yaitu wanita ingin tampil lebih konsumtif dibanding pria dan menurut Sumarwan, dkk (2011) wanita merupakan konsumen potensial bagi para produsen untuk menawarkan produk-produknya.

\section{Karakteristik responden}

Tabel 1. Karakteristik Responden

\begin{tabular}{lrr}
\hline \multicolumn{1}{c}{ Deskripsi } & $\begin{array}{r}\text { Jumlah } \\
\text { (orang) }\end{array}$ & $\begin{array}{r}\text { Persentase } \\
\text { (\%) }\end{array}$ \\
\hline Usia & 39 & $65 \%$ \\
$15-22$ tahun & 18 & $30 \%$ \\
$23-29$ tahun & 3 & $5 \%$ \\
$30-36$ tahun & & $45 \%$ \\
\hline Jenis Kelamin & 27 & $55 \%$ \\
Laki-laki & 33 & $11,7 \%$ \\
Perempuan & & $8,3 \%$ \\
\hline Jenis Pekerjaan & 7 & $23,3 \%$ \\
Wiraswasta & 5 & $56,7 \%$ \\
Pegawai Negeri & 14 & \\
Pegawai Swasta & 34 & \\
Mahasiswa dan Pelajar & & \\
& & \\
\hline
\end{tabular}

\section{Kesadaran Merek Filosofi Kopi}

Berdasarkan hasil dari penyebaran kuesioner dengan skala semantik diferensial kepada responden yang datang mengenai sikap penilaian manajemen kesadaran merek yang sudah dilakukan oleh Filosofi Kopi setelah diolah menjadi diagram ular adalah sebagai berikut: 


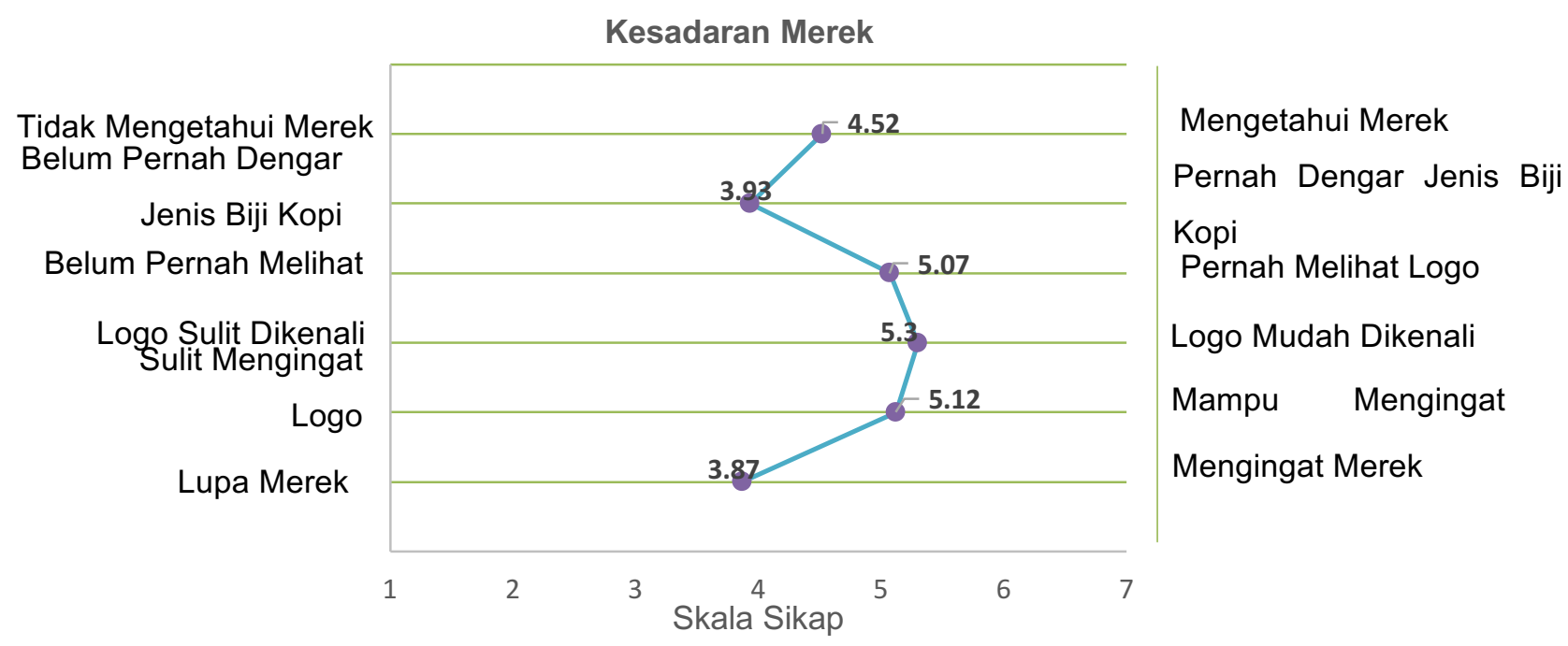

Gambar 2. Diagram Ular Kesadaran Merek Filosofi Kopi

Berdasarkan diagram ular di atas maka dapat dilihat bahwa variabel kesadaran merek lebih condong ke arah kanan atau ke arah yang bernilai positif. Hal ini merupakan indikasi positif bagi Filosofi Kopi sebagai pendatang baru di industri coffee house yang menunjukkan bahwa merek perlu dilihat bukan hanya sekedar atribut produk namun memiliki beberapa dimensi yang dapat dijadikan diferensiasi sebuh produk dengan produk lainnya (Kotler, 2013). Pengunjung mengetahui merek Filosofi Kopi dengan nilai rata-rata 4,52, pengunjung rata-rata mayoritas sudah pernah melihat logo Filosofi Kopi yaitu di dalam coffee house, film, dan instagram dengan rata-rata nilai 5,07, logo Filosofi Kopi dinilai mudah untuk dikenali oleh konsumen dengan memperoleh nilai rata-rata 5,3 hal tersebut disebabkan karena bentuk logo yang mudah untuk diingat dan bentuknya yang unik, Logo yang dinilai unik ini lah yang membuat konsumen menjadi mudah untuk mengingatnya hal ini terlihat dari nilai rata-rata yang diperoleh dari hasil kuesioner terhadap responden yaitu sebesar 5,12 dari nilai skala sikap 7 . Hasil ini sejalan dengan penelitian yang menyatakan bahwa membangun kesadaran merek dapat meningkatkan kemungkinan bahwa merek tersebut dapat menjadi bagian dari pengambilan keputusan konsumen saat akan membeli atau menggunakan produk tersebut (Baker dkk, 1986; Nedungadi, 1990).Sehingga jika konsumen telah mengenal logo merek sebuah produk dan selanjutnya saat konsumen akan melakukan pembelian tidak perlu lagi melihat label tulisan merek namun cukup mengenalinya dari atribut merek lainnya yaitu logo.

Namun, terdapat hal menarik pada diagram alur kesadaran merek tersebut yaitu ternyata tidak semua indikator yang digunakan menunjukkan hasil yang positif tetapi terdapat juga nilai yang condong ke arah negatif. Indikator yang lebih condong ke arah negatif adalah pengetahuan mengenai jenis biji kopi yang dijual di Filosofi Kopi dan kemampuan untuk mengingat merek Filosofi Kopi diantara coffee house lainnya dengan nilai rata-rata secara berturut-turut adalah sebesar 3,93 dan 3,87 . Hal ini salah satu kelemahan pengenalan merek kopi yang disajikan oleh Filosofi Kopi, karena kesadaran merek melalui pengenalan merek oleh konsumen akan terkait dengan kemampuan konsumen untuk mengkonfirmasi penekanan sebelumnya yang telah dilakuka oleh perusahaan atas merek saat merek tersebut dijadikan sebagai alat pengenal produk awal. Hal ini mengandung arti bahwa konsumen harus dengan tepat mampu membedakan merek yag ada di pasar dan konsumen telah terlebih dahulu melihat atau mendengar merek tersebut sebelumnya sebelum melakukan pembelian kembali di masa yang akan dating (Keller, 1993). Maka dapat disimpulkan bahwa kopi lokal yang 
ditawarkan dan menjadi unggulan produk yang ditawarkan Filosofi Kopi belum dikenal oleh konsumen.

\section{Kualitas Produk Kopi di Filosofi Kopi}

Hasil dari penyebaran kuesioner dengan skala semantik diferensial kepada responden yang datang mengenai penilaian manajemen kualitas produk yang sudah dilakukan oleh Filosofi Kopi setelah diolah menjadi diagram ular yang ditampilkan oleh Gambar 3.

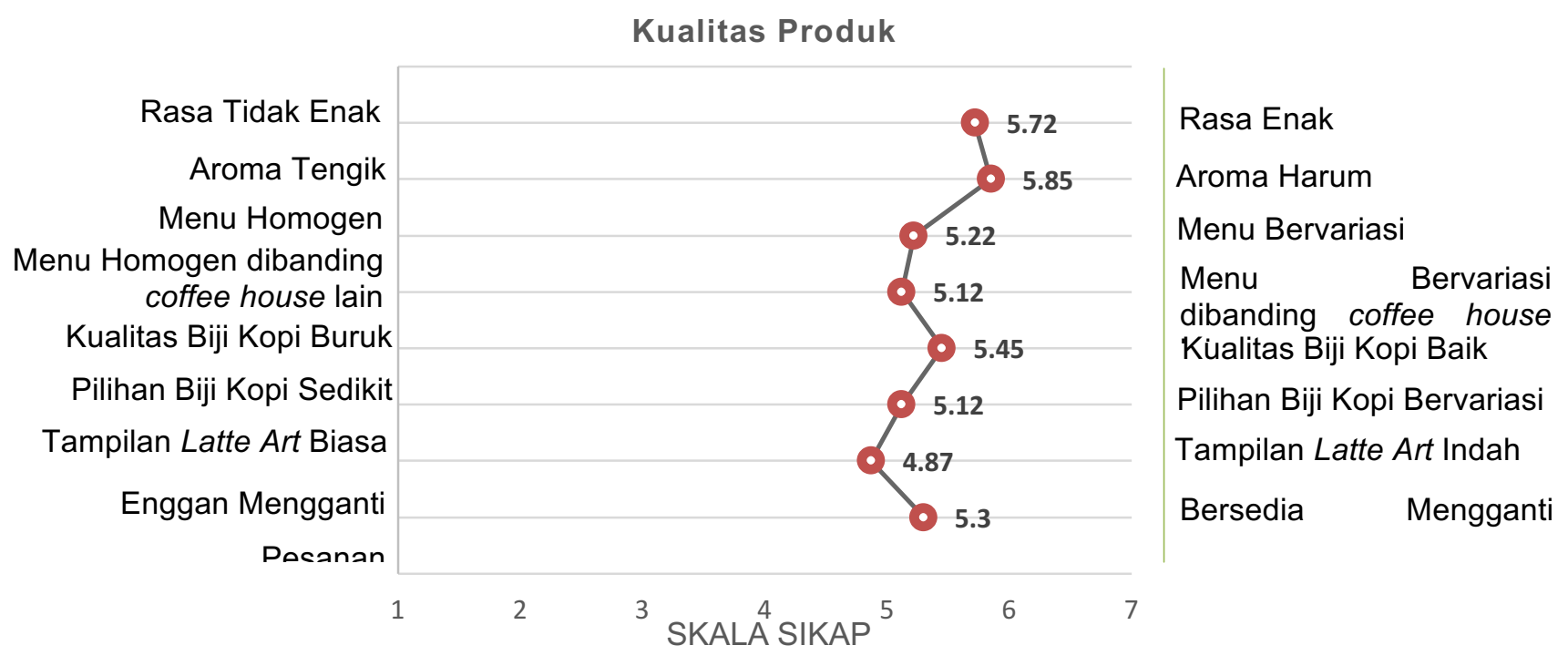

Gambar 3. Diagram Ular Kualitas Produk di Filosofi Kopi

\begin{abstract}
Diagram ular mengenai variabel kualitas produk menunjukkan bahwa setiap indikator yang mewakili kualitas produk memiliki nilai yang condong ke arah positif. Para pengunjung menilai rasa minuman kopi yang disajikan di Filosofi Kopi termasuk ke dalam kategori rasa yang enak dengan nilai rata-rata 5,72 tetapi walaupun demikian, komentar para pengunjung tersebut lebih banyak yang mengatakan bahwa mereka tidak terlalu mengerti tentang kopi, aroma kopi yang disajikan juga mendapatkan nilai sikap yang positif yaitu sebesar 5,85 dan sama halnya seperti indikator rasa kopi, ternyata mayoritas berkomentar tidak terlalu paham mengenai kopi, menu minuman kopi di Filosofi Kopi yang bervariasi dengan nilai rata-rata 5,22 menyebabkan konsumen dapat memilih tidak hanya kopi yang dibuat menggunakan mesin tetapi bisa juga dengan teknik manual brewing tetapi menu tersebut jika dibandingkan dengan menu di coffee house lainnya dinilai dengan nilai rata-rata yang lebih rendah yaitu sebesar 5,12 . Kualitas produk yang dinilai konsumen secara positif selajan dengan penelitian lain yang menyatakan
\end{abstract}

bahwa kualitas produk memiliki pengaruh terhadap nilai (Dhanya \& Thomas, 2011; Busrita dkk, 2015). Penilaian konsumen terhadap kualitas produk dapat menjadi salah satu indicator kesuksesan sebauh produk untuk berusaha menawarkan produk yang sesuai dengan kebutuhan dan keinginan konsumen sehingga produk akan nilai tinggi oleh konsumen sebagai konsekuensi kualitas produk yang tinggi. Kualitas biji kopi yang disediakan Filkop yaitu Perfecto, Tiwus, dan Lestari dinilai baik oleh para pengunjung dengan nilai rata-rata sebesar 5,45 , pilihan biji kopi ini pun dinilai bervariasi menurut mayoritas pengunjung yang datang dengan nilai rata-rata sebesar 5,12 namun terdapat komentar dari pengunjung tersebut yaitu untuk menambahkan pilihan jenis biji kopi dari seluruh nusantara. Konsumen perlu mengetahui kualitas produk, karena saat melakukan pemilihan produk konsumen akan berupaya untuk mengetahui dengan pasti produk seperti apa yang akan mereka beli dan konsumen tidak akan membuang - buang waktu untuk membeli produk yang tidak sesuai 
dengan keinginan konsumen (Dhanya \& Thomas, 2011). Latte art merupakan cara menyajikan kopi dengan menuangkan susu panas ke secangkir espresso dan menciptakan pola atau desain di permukaannya. Latte art pada minuman kopi di Filosofi Kopi dinilai indah oleh pengunjung yang datang yaitu dengan nilai rata-rata sebesar 4,87.

Menurut para pengunjung memang sudah seharusnya jika terjadi kesalahan pada pesanan harus diganti oleh barista yang membuatnya, hal tersebut memiliki nilai rata-rata sebesar 5,3 , berdasarkan dari pengakuan salah satu barista mengatakan bahwa sampai saat ini belum pernah terjadi kesalahan pada penyajian pesanan tetapi yang terkadang terjadi adalah penyajian pesanan yang seharusnya dimiliki oleh pemesan pertama disajikan terakhir sedangkan pesanan yang terakhir disajikan lebih dulu sehingga pemesan yang pertama harus menunggu lebih lama dari yang seharusnya. Hal tersebut terjadi saat keadaan coffee house sedang ramai seperti pada hari sabtu dan minggu yang merupakan akhir pekan.

\section{Kualitas Pelayanan di Filosofi Kopi}

Hasil dari penyebaran kuesioner mengenai penilaian manajemen kesadaran merek yang sudah dilakukan oleh Filkop setelah diolah menjadi diagram ular adalah sebagai berikut:

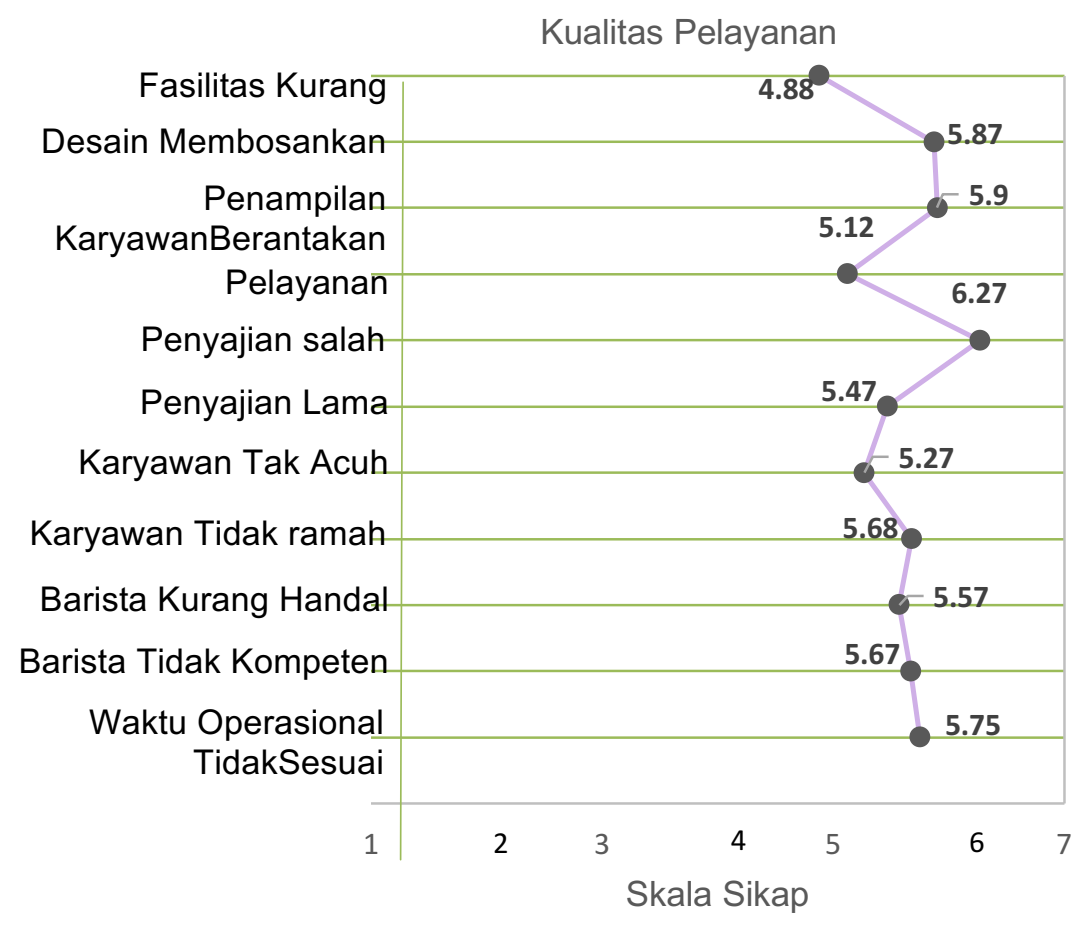

Fasilitas Memadai

Desain Menarik

Penampilan Karyawan Rapih

Pelayanan Memuaskan

Penyajian Benar

Penyajian Cepat

Karyawan Acuh

Karyawan Ramah

Barista Profesional

Barista Kompeten

Waktu Operasional Sesuai

Gambar 4. Diagram Ular Kualitas Pelayanan di Filosofi Kopi

Pada diagram ular variabel kualitas pelayanan dapat dilihat bahwa semua indikator yang digunakan sebagai penilaian kualitas pelayanan di Filosofi Kopi cenderung ke arah yang positif. Fasilitas yang disediakan di Filsoofi Kopi dinilai oleh para pengunjung sudah cukup memadai dengan nilai rata-rata sebesar 4,88. Saran dari konsumen yang terpenting adalah bahwa mayoritas dari pengunjung menyarankan untuk memperluas coffee house dan juga menambahkan meja serta kursi.
Perusahaan yang melakukan bisnis di industry jasa makanan perlu memperhatikan bagaimana kualitas pelayanan disampaikan kepada konsumen sebagai bentuk pengukuran sejauh mana layanan mampu memenuhi kebutuhan dan harapan konsumen (Lewis dalam Akbar, 2009).

Berdasarkan hasil kuesioner yang menanyakan mengenai hal apakah yang menjadi daya tarik bagi para pengunjung untuk datang ke Filosofi Kopi menunjukkan hasil pada peringkat 
pertama yaitu karena ingin melihat tempatnya seperti yang ada di dalam film. Faktor tempat yang menjadi daya tarik utama dari Filosofi Kopi disebabkan karena desain interiornya yang dinilai unik dengan mengusung konsep dengan tema yang unik yaitu vintage atau old school. Desain interior yang unik dan menarik ini dinilai oleh pengunjung dengan nilai rata-rata sebesar 5,87 . Hal ini sejalan dengan penelitian lain dilakukan terkait dengan kualitas pelayanan yang menyatakan bahwa kualitas secara tidak langsung terkait dengan perilaku konsumen terutama keinginan konsumen untuk membeli produk yang slenajutnya terkait dengan loyalitas konsumen (Anderson dan Sullivan, 1994).

Indikator lain dari kualitas pelayanan Filosofi Kopi adalah karyawan Filosofi Kopi berpenampilan rapih yang diberi nilai oleh para pengunjung sebesar 5,9. Pelayanan yang diberikan oleh karyawan Filosofi Kopi dinilai memuaskan dengan nilai sebesar 5,12, untuk penyajian minuman kopi yang ada di Filosofi Kopi sesuai dengan pesanan yang dipesan oleh pengunjung dan kecepatan penyajiannya pun dinilai cepat yaitu tergantung dari jenis pesanan kurang lebih sekitar 5 menit, hal ini diberikan nilai secara berturut-turut sebesar 6,27 dan 5,47.

Berdasarkan jawaban dari hasil kuesioner terhadap responden yang datang ke Filosofi Kopi menunjukkan bahwa karyawan Filosofi Kopi peduli terhadap pengunjung yang termasuk ke dalam waiting list dengan nilai sebesar 5,27 . Walaupun pengunjung menilai sikap karyawan (barista dan kasir) dalam hal pelayanan adalah memuaskan tetapi dalam hal keramahan, pengunjung menyatakan bahwa karyawan kurang ramah dan kurang senyum ketika pengunjung melakukan pemesanan. Namun secara garis besar tentang keramahan karyawan tersebut, pengunjung menilai bahwa barista dan kasir cukup ramah dengan nilai sebesar 5,68 .

Penilaian oleh pengunjung yang datang ke Filosofi Kopi terhadap barista dinilai profesional dengan nilai rata-rata 5,57 . Pengunjung yang datang ke
Filosofi Kopi tidak semuanya memahami betul mengenai kopi sehingga saat melakukan pemesanan mereka selalu bertanya terlebih dahulu kepada pihak kasir atau pun barista dan dijawab secara kompeten. Hal tersebut didasarkan dari hasil kuesioner terhadap responden yang menilai pengetahuan barista dan kasir mengenai kopi yang disajikan di Filosofi Kopi adalah kompeten dengan nilai sebesar 5,67. Pengunjung yang datang ke Filkop selalu silih berganti setiap harinya. Waktu operasional Filkop dianggap sesuai oleh pengunjung yang datang dengan nilai rata-rata sebesar 5,75 . Berdasarkan penilaian konsumen atas kualitas pelayanan thematic coffee house Filosofi Kopi menunjukkan bahwa secara keseluruhan atribut kualitas pelayanan yang disediakan dijadikan sebagai upaya perusahaan untuk memuaskan konsumen. Kualitas pelayanan merupakan factor penting sebagai media evaluasi konsumen dan untuk menentukan kepuasan konsumen (Zeithaml dkk, 2006). Artinya apabila perusahaan berupaya untuk menyediakan pelayanan yang maksimal bagi konsumen maka hal ini akan berpotensi untuk meningkatkan kepuasan konsumen dan kelangsungan bisnis dalam jangka panjang. Kesuksesan sebuah perusahaan yang menyediakan jasa akan berasal dari kualitas pelayanan yang akan menggiring kepuasan konsumen (Bateson, 1995)

\section{Nilai Pelanggan Filosofi Kopi}

$\begin{gathered}\text { Setelah melihat hasil dari } \\ \text { perbandingan penerapan }\end{gathered}$
manajemen kesadaran merek, kualitas
produk, dan kualitas pelayanan oleh
Filosofi Kopi dengan yang dirasakan
oleh pengunjung, maka dapat dilihat
bagaimanakah nilai pelanggan yang
dirasakan akibat setelah mengkonsumsi
produk minuman kopi yang disajikan di
Filosofi Kopi. Berdasarkan hasil dari
penyebaran kuesioner dengan skala
semantik diferensial kepada responden
yang datang ke Filosofi Kopi setelah
diolah menjadi diagram ular seperti yang
ditampilkan pada Gambar 5.




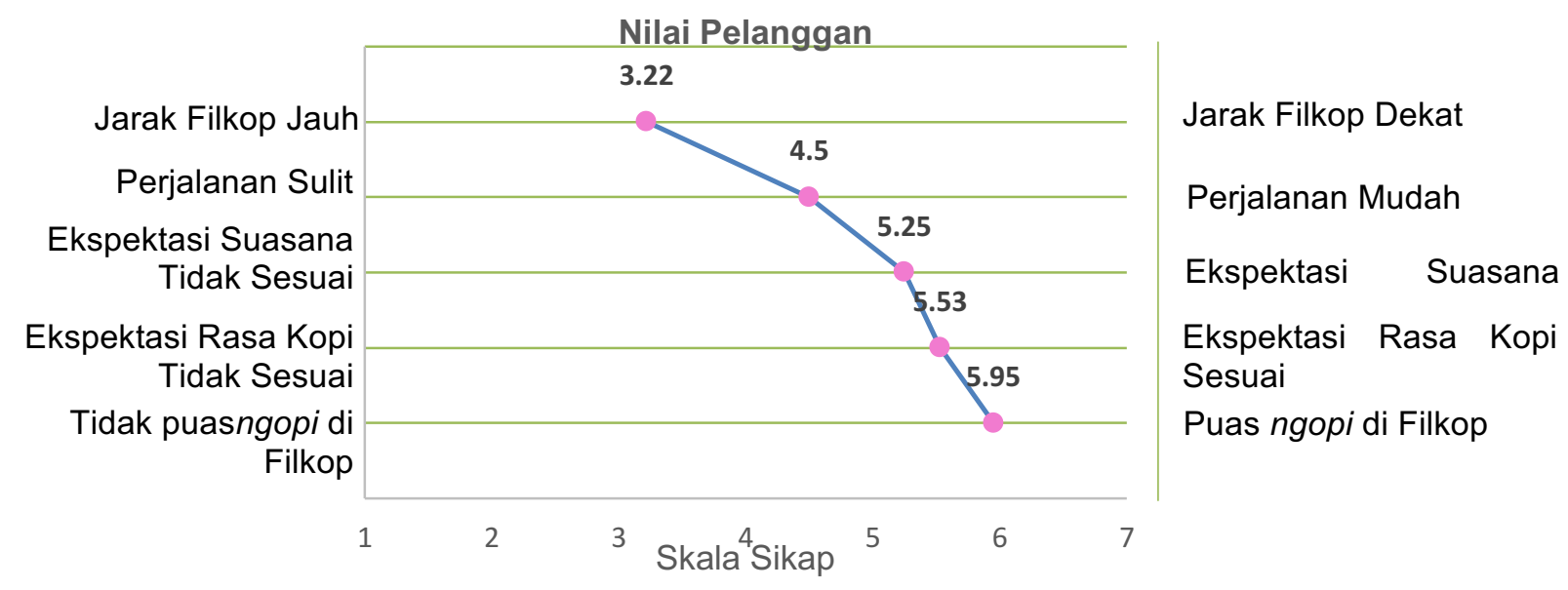

Gambar 5. Diagram Ular Nilai Pelanggan Filosofi Kopi

Berdasarkan diagram ular dari variabel nilai pelanggan yang diperoleh oleh pengunjung yang datang ke Filosofi Kopi menunjukkan bahwa indikator perjalanan, ekspektasi suasana, ekspektasi rasa kopi, dan kepuasan ngopi di Filosofi Kopi cenderung ke arah sikap yang positif sedangkan untuk indikator jarak cenderung ke arah sikap yang negatif. Hal tersebut dikarenakan oleh para pengunjung lebih banyak yang berasal dari daerah yang jauh atau di luar daerah Jakarta Selatan. Jarak dari tempat pengunjung ke Filosofi Kopi dinilai jauh sehingga nilai rata-rata menunjukkan sebesar 3,22. Namun hal tersebut menunjukkan bahwa pengunjung walaupuan berasal dari tempat yang jauh tetap bersedia meluangkan waktu, tenaga, dan juga biaya untuk datang ke Filosofi Kopi karena rasa penasaran mereka terhadap tempat coffee house, rasa kopinya, dan juga ingin bertemu dengan salah satu pemilik dari Filosofi Kopi tersebut. Gaya hidup modern yang dijalankan oleh konsumen di kota - kota besar merupakan dampak dari kondisi ekonomi jasa yang berkembang saat ini bagaimana memenuhi harapan konsumen dan untuk mengukur kepuasan konsumen yang menjadi fokus penciptaan nilai (Parasuraman dkk, 1988; Gorst dkk, 1998).

$\begin{array}{llr}\text { Nilai yang diterima oleh } & \text { ol } \\ \text { konsumen bukan hanya dinilai } & \text { han } \\ \text { berdasarkan manfaat yang diterima atas } \\ \text { konsumsi produk namun juga } \\ \text { pengorbanan yang dilakukan oleh }\end{array}$

konsumen baik dinilai secara materiil maupun imateriil. Melalui nilai pelanggan dapatd ilihat perbedaan antara manfaat yang dllihat seorang pelanggan atas sebuah penawaran serta biaya untuk mendapatkan manfaat tersebut (Cannon dkk, 2008).Salah satu pengorbanan imateriil adalah perjalanan yang ditempuh oleh pengunjung untuk dapat sampai ke Filosofi Kopi dinilai cukup mudah dengan nilai rata-rata 4,5. Lokasi Filosofi Kopi yang berada di dekat terminal Blok $M$ memudahkan para pengunjung yang menggunakan kendaraan umum seperti halnya bus kota dan transjakarta. Namun karena berlokasi di daerah Blok $M$ yang memang setiap harinya macet membuat pengunjung yang menggunakan kendaraan pribadi harus melewati kemacetan terlebih dahulu. Setiap pengunjung memiliki ekspektasi yang berbeda-beda terhadap tempat serta suasana dan juga rasa kopi yang disajikan di Filosofi Kopi tersebut, apakah sama seperti yang dideskripsikan di film Filosofi Kopi atau tidak. Mayoritas pengunjung menyatakan bahwa tempat atau suasana dan rasa kopi yang disajikan oleh Filosofi Kopi sesuai dengan ekspektasi mereka yaitu secara berturut-turut sebesar 5,25 dan 5,53. Para pengunjung tersebut menyatakan mereka puas ngopi di Filosofi Kopi karena dapat merasakan suasana seperti sedang berada di dalam film Filosofi Kopi dengan memberikan penilaian sebesar 5,95 . Penentuan nilai pelanggan dalam mengukur manfaat 
produk melalui kualitas dan merek yang dilakukan pada penilitian ini sejalan dengan hasil penelitian lain mengenai nilai yang dipersepsikan pelanggan yang menyatakan bahwa kunci penting dari memahami nilai pelanggan adalah dengan mengukur persepsi konsumen atas kualitas atau kinerja dan pengorbanan moneter serta perilaku minat beli konsumen atas produk (Patterson dan Spreng, 1997), meskipun nilai memiliki karekter yang multidimensional baik secara persepsi kualitas, harga, loyalitas merek, kemampuan pengenalan produk di mata konsumen dan persepsi atas risiko (Monroe dan Krishnan, 1985; Cronin dkk, 2000; Harcar dkk; 2006).

\section{KETERBATASAN PENELITIAN DAN PELUANG PENELITIAN DI MASA YANG AKAN DATANG}

Penelitian ini hanya melakukan deskripsi dan penggambaran terhadap persepsi konsumen terhadap merek, kualitas, produk, kualitas pelayanan dan nilai pelanggan sebuah thematic coffee house yang baru dikembangkan di Jakarta sebagai kota dengan konsumen yang heterogen dan representasi wilayah pasar potensial bagi gaya hidup modern yang berkemabang saat ini. Namun demikian, pada penelitian ini belum dilakukan pengujian terhadap pengaruh antar variabel yang diteliti untuk memberikan justifikasi serta verifikasi yang lebih akuran terhadap keterkaitan antar variabel yag diteliti, Sehingga pada penlitian selanjutnya dapat dilakukan pengujian untuk membuat verifikasi hubungan epmiruk antar varaibel serta mengetahui sebarapa besar kontribusi antar varaibel yang diteliti pada penlitian ini terutama terhadap factor nilai pelanggan yang saat ini tengah berkembang konsepnya sebagai salah satu alat ukur keberhasilan produk di pasar melalui sudut pandang konsumen sebagai kunci sukses pemasara produk.

\section{KESIMPULAN DAN SARAN}

Kesadaran merek Filosofi Kopi di
mata konsumen dinilai belum optimal karena pengunjung masih memiliki kecenderungan lebih mudah mengingat logo namun sulit untuk mengingat merek bahkanuntuk jenis kopi lokal yang dijual belum pernah didengar atau diketahui oleh konsumen seperti merek biji kopi Perfecto, Tiwus, dan Lestari yang digunakan dan dijual di Filosofi Kopi. Intensi awal pelanggan yang datang ke coffee housedatang karena tertarik dengan konsep rumah kopi yang dibuat berdasarkan sebuah judul film dengan judul yang sama. Filosofi Kopi juga belum menjadi salah satu pilihan utama coffee house yang muncul di benak konsumen ketika ingin menikmati secangkir kopi.

Kualitas memang tidak dapat didefinsikansecara tepat, namun kualitas merupakan konsep yang sederhana dan meskipun kualitas merupakan properti yang tidak dapat dianalisis dengan pasti namun merupakan sebuah hal yang dapat dikenali melalui pengalaman secara terus - menerus Parasuraman, Zeithamal, and Berry, 1985). Hasil analisis yang menunjukkan kualitas produk yang dianggap superior oleh konsumen adalah rasa kopi yang enak dan aroma kopi yang harum namun kreasi latte art yang disajikan masih kurang menarik konsumen, sedangkan kualitas pelayanan yang dilakukan di Filosofi Kopi dipersepsikan konsumen sudah sesuai dengan harapan konsumen adalah penyajian kopi yang benar dan penampilan karyawan yang rapi sehingga menarik konsumen namun belum dapat menyediakan fasilitas pelayanan yang lengkap untuk meningkatkan kepuasan konsumen.

Sementara itu, konsumen menganggap nilai atas Filosofi Kopi secara keseluruhan mampu memberikan kepuasan konsumen meskipun rata rata konsumen membutuhkan pengorbanan yang cukup jauh secara jarak untuk dapat datang dan menikmati kopi di Filosofi Kopi. Sehingga untuk jenis coffee house yang menonjolkan keunikan secara tema usaha namun juga ingin menampilkan keunikan dan kekhasan produk yang dipasarkan maka selain memberikan kepuasan secara kualitas produk juga perlu adanya upaya pendukung memberikan kualitas 
pelayanan yang maksimal untuk meningkatkan nilai yang dirasakan pelanggan sehingga konsumen menjadi puas yang akan memimbulkan pembelian berulang di masa yang akan datang.Kualitas merupakan konstruk yang kadang teraibaikan namun merupakan kunci untuk meraih daya saing di dalam pasar persaingan global (Monirul \& Han, 2012).

Jenis usaha coffee house lokal hendaknya memiliki kesadaran merek yang tinggi di dalam perspektif konsumen sebagai upaya komunikasi pemasaran di dalam persaingan bisnis coffee shop yang ketat di kota - kota besar. Upaya lain untuk mengoptimalkan pemasaran produk adalah melalui peningkatan kualitas produk dan pelayanan untuk meningkatkan nilai pelanggan serta memberikan edukasi yang lebih intensif mengenai jenis kopi lokal yang dijual kepada pelanggan sebagai keunggulan bersaing di dalam food service industri.

\section{DAFTAR PUSTAKA}

Aaker, D.A. 2002. Building Strong Brands. 1st Edition. London : Free Press.

Akbar, M.M., Parvez, Noorjahan. 2009. Impact of Service Quality, Trust, and Customer Satisfaction on Customer Loyalty. ABAC Journal, vol. 29 , no. 1 , pp. 24-38.

Alex, Dhanya \& Thomas, Sam. 2011. Impact of Product Quality, Service Quality and Contextual Experience on Customer Perceived Value and Future Buying Intentions, Journal of Business and Management, vol. 3, no. 3, pp. 307-315.

Anderson, E. W., Sullivan, 1994. Consumer Satisfaction, Market Share, and Profitability? Findings from Sweden. Journal of Marketing. 58(3), pp.53-66.

Badan Pusat Statistik. www.bps.go.id. Diakses pada 13 Januari 2016.

Baker, William, J. Wesley Hutchinson, Danny Moore, danPrakash Nedungadi.1986. Brand Familiarity andAdvertising: Effects on the Evoked Set and Brand Freferences.Advances
Consumer Research, Vol. 13, ed.Richard J. Lutz, Provo, UT: Association for ConsumerResearch, pp.146-147.

Bateson, J. 1995. Managing Services Marketing: Text and Readings (Third Edition). Fort Worth, TX: The Dryden Press, Harcourt Brace College Publishers

Busrita, Y.P., Kamela, Ice., Irda. 2015. Analisis Pengaruh Kesadaran Merek, Persepsi Kualitas, dan Loyalitas Merek Terhadap Nilai Pelanggan Smartphone Samsung di Kota Padang. Jurnal Manajemen, vol. 6, no.2.

Cannon, J.P., dkk. 2008. Pemasaran Dasar. Edisi 16. Jakarta : Salemba Empat.

Cronin, J. M., M. Brady, and T.M. Hult/ 2000. Assessing the Effects of Quality, Value, and Customer Satisfaction on Consumer Behaviorallntentions in Service Environments/ Journal of Retailing, vol.76, no.2, pp. 193-218.

Dhanya, Alex\& Thomas, Sam. 2011. Impact of Product Quality, Service Quality and Contextual Experience on Customer Perceived Value and Future Buying Intentions/ Journal of Business and Management, vol. 3, no. 3, pp. 307-315.

Euromonitor. 2012 Consumer FoodService - Indonesia.

Food and Agriculture Organization of United Nation (FAO). 2015. www.faostat.fao.org

Gay, L.R. \& Diehl, P.L. 1992. Research Methods for Business and Management. New York : MacMillan Publishing Company.

Gorst, J. et al. 1998. Providing Customer Satisfaction. Total Quality Management. Vol.9. no 4\&5. pp.100-103/

Hair, J.F., W.C. Black, B.J. Babin, R.E. anderson, R.L.Tatham. 2006. Multivariate Data Analysis, 6th Edition. New Jersey : Prentice Hall.

Hanzaee, K.H. \& Yazd, R.M. 2010, The Impact of Brand Class, Brand Awareness, and Prices on Two Important Consumer Behavior Factors; Customer Value and Behavioral Intentions, Journal of 
Business Management, vol. 4(17), pp. 3775-3784.

Harcar, T., Kara, A., \& Kucukemiroglu, O. 2006. Consumer's Perceived Value And BuyingBehavior of Store Brands: An Empirical Investigation. The Business Review, Cambridge, Vol.5, no.2. pp.55-62

Johnston, Robert. 1995. The Determinants of Service Quality: Satisfiers and Dissatisfiers. International Journal of Service Industry Management, vol. 6, no.2, pp.53-71.

Keller, K. L. 1993. Conceptualizing, Measuring, And Managing Customer-BasedBrand Equity, Journal of Marketing, Vol. 57, Januari.

Keller, K.L. 2013. Strategic Brand Management. 4th Edition. England : Pearson.

Kotler, P., Keller, K.L., Brady, M., Goodman, M. \& Hansen, T. 2009. Marketing Management. 13th Edition. England : Pearson Education.

Kotler, Philip \& Keller, K. L. 2006. Marketing Management. 12th Edition. New Jersey : Prentice Hall. Monirul, I. M.,\&Han, J. H. 2012. Perceived Quality and Attitude toward Tea \& Coffee byConsumers. International Journal of Business Research and Management (IJBRM), Vol.3, no. 3. pp.100-112.

Monroe, Kent B. and R. Krishnan. 1985. The Effect of Price on Subjective Product Evaluationsin Perceived Qualityl J. Jacoby and J. Olson, eds. Lexington, MA: LexingtonBooks, 209-32.

Nedungadi. P. 1990.Recall and Consumer Consideration Sets: Influencing Choice without Altering Brand Evaluations. Journal of Consumer Research, Vol. 17 No. 1, pp. 263-276.

Parasuraman, A., V.A. Zeithaml, and L.L. Berry (1985).A Conceptual Model of Service Quality and Its Implications for Future Research. Journal of Marketing, vol.49, pp.41-50.

Parasuraman, A., Zeithaml, and L.L. Berry. 1988. A Multiple-item scale for measuring Consumer Perception of Service Quality. Journal of Retailing, Vol.64. pp. 1240.

Patterson, P.G. dan R.A Spreng, 1997. Modelling The Relationship Between Perceived Value, Satisfaction And Repurchase Intentions In A Business-ToBusiness, Services Context: An Empirical Examination. International Journal of Service Industry Management, vol.8, no.5. pp. 414-434.

Qin, Hong., Prybutok, V.R. 2009. Service Quality, Customer Satisfaction, and Behavioral Intentions in FastFood Restaurants. International Journal of Quality; Relilability Management, vol. 21, pp.545-563.

Sarwono, Jonathan. 2009. Statistik Itu Mudah: Panduan Lengkap untuk Belajar Komputasi Statistik Menggunakan SPSS 16. Yogyakarta : Universitas Atma Jaya.

Utami, H.N., Sadeli, A.H., Perdana, Tomy. 2016. Customer Value Creation of Fresh Tomatoes Through Branding and Packaging as Customer Perceived Quality. International Society for Southeast Asian Agricultural Sciences Philippines,. vol. 22, pp.123-136.

Zeithaml, V. A., Parasuraman, A., and Berry, L., 1990. Delivering Quality Service: Balancing Customer Perception and Expectations. New York: Free Press.

Zeithaml, V.A., Bither, M.J, \& Gremler, D.D. 2006. Service Marketing: Integrating Customer Focus Cross Firm (Fourth Edition). New York, NY: McGraw-Hill. 